\title{
PENGARUH KUALITAS LAYANAN TERHADAP KEPUASAN PASIEN RAWAT INAP PADA RSUD KABUPATEN BANGGAI KEPULAUAN
}

\author{
MAGVIRA ALIA \\ NIRWAN \\ SUARDI \\ Prodi Manajemen, Fakultas Ekonomi, Universitas Tadulako \\ Email: Magviraalia115@gmail.com
}

\begin{abstract}
The study intends to determine simultaneous and partial influence of service quality $(X)$ consisting of physical evidence (X1), reliability (X2), responsiveness (X3), assurance (X4), and empathy (X5) on patient satisfaction $(Y)$ in the General Hospital of Banggai Islands, where the study is located. The type of research is descriptive. Sources of data is primary data retrieved from questionnaires and secondary data obtained from documents of the Regional General Hospital Banggai Islands. The sample consists of 72 respondents. The sampling technique used is purposive sampling. Based on the results, it is shown that the quality of service $(X)$, consisting of physical evidence $(X 1)$, reliability $(X 2)$, responsiveness (X3), assurance (X4), and empathy (X5) simultaneously have significant influence on patient satisfaction $(Y)$ of $69.60 \%$ while the remaining $30.40 \%$ is influenced by other causes. Partial test shows that there are three independent variables: physical evidence (X1), reliability (X2) and assurance (X4) that have non-significant influence to the patients' satisfaction at the General Hospital of Banggai Islands.
\end{abstract}

Keywords: service quality, patient satisfaction

Abstrak

Tujuan dari penelitian ini adalah untuk mengetahui pengaruh kualitas layanan (X) yang terdiri dari bukti fisik (X1), reliabilitas (X2), responsivitas (X3), jaminan (X4), dan empati (X5) secara simultan dan parsial terhadap kepuasan pasien. (Y) di Rumah Sakit Umum Kepulauan Banggai. Lokasi penelitian ini di Rumah Sakit Umum Kepulauan Banggai. Jenis penelitian ini bersifat deskriptif. Sumber data dalam penelitian ini adalah data primer yang diambil melalui kuesioner dan data sekunder diperoleh dari Rumah Sakit Umum Daerah Banggai. Sampel dalam penelitian ini adalah 72 responden. Teknik sampling yang digunakan adalah purposive sampling. Berdasarkan hasil penelitian menunjukkan bahwa variabel kualitas pelayanan (X) yang terdiri dari bukti fisik (X1), reliabilitas (X2), responsivitas (X3), jaminan (X4), dan empati (X5) secara simultan berpengaruh signifikan terhadap kepuasan pasien (Y) dengan pengaruh $69,60 \%$ sedangkan sisanya $30,40 \%$ dapat dijelaskan oleh penyebab lainnya. Uji parsial menunjukkan bahwa terdapat tiga variabel bebas yang tidak signifikan yaitu bukti fisik (X1), reliabilitas (X2) dan jaminan (X4) terhadap kepuasan pasien di Rumah Sakit Umum Kepulauan Banggai.

Kata kunci: Kualitas Pelayanan, Kepuasan Pasien

\section{PENDAHULUAN}

\section{Latar Belakang Penelitian}

Salah satu kebutuhan manusia yang menjadi prioritas mendasar adalah kesehatan. Kesehatan merupakan hal yang terpenting dalam kehidupan manusia. Karena dengan menjaga kesehatan yang optimal, seseorang dapat menjalankan aktivitasnya dengan baik. Terwujudnya kondisi yang sehat adalah salah satu harapan semua orang, sehingga upaya dalam mewujudkan kondisi yang sehat tersebut, maka harus dilakukan beberapa hal salah satunya adalah menyelenggarakan kesehatan bagi masyarakat.

Rumah Sakit dapat memberikan pelayanan kesehatan yang bermutu terjangkau oleh masyarakat dalam rangka meningkatkan derajat kesehatan masyarakat, pelayanan ini bersifat dasar dengan mengutamakan sarana kesehatan dengan menyelenggarakan kesehatan secara merata yang 
mengutamakan upaya penyembuhan penyakit dan pemulihan kepada masyarakat. Rumah sakit adalah bagian yang penting di bidang kesehatan dan berperan dalam menunjang kelangsungan hidup masyarakat agar hidup sehat dan sejahtera, di rumah sakit mempunyai beberapa ruang baik untuk pengobatan, pelayanan, informasi, bagian paramedis (catatan pengobatan pasien) salah satunya Kabupaten Banggai Kepulauan hanya memilki satu Rumah sakit dan merupakan salah satu alternatif tempat masyarakat berobat.

Berdasarkan data selama tiga tahun terakhir jumlah pasien rawat inap di Rumah Sakit Umum Kabupaten Banggai Kepulauan terlihat pada Tabel 1. berikut ini.

Tabel 1 Jumlah Pasien Rawat Inap Pada Rumah Sakit Umum Daerah Kabupaten Banggai Kepulauan Tahun Anggaran 2013 - 2015

\begin{tabular}{ccc}
\hline NO & Tahun & Jumlah Pasien Rawat Inap \\
\hline 1 & 2013 & 989 \\
2 & 2014 & 1.124 \\
3 & 2015 & 1.090 \\
\hline
\end{tabular}

Sumber : Rumah Sakit Umum Daerah Kabupaten Banggai Kepulauan 2015

Berdasarkan data di atas, dapat dilihat bahwa pada tahun 2013 jumlah pasien rawat inap berjumlah 989 orang meningkat pada tahun 2014 berjumlah 1.124 orang dan menurun pada tahun 2015 berjumlah 1.090 orang. Hal ini diduga, karena kemungkinan adanya kesenjangan antara harapan pasien dan pelayanan yang diberikan oleh pihak Rumah Sakit Umum Kabupatan Banggai Kepulauan. Disamping itu, pihak Rumah Sakit Umum Kabupatan Banggai Kepulauan telah melakukan fungsinya sebagai sebuah lembaga pelayanan kesehatan bagi masyarakat.

Jika layanan yang diberikan sesuai dengan yang dikehendaki, maka pasien akan puas, jika yang terjadi sebaliknya maka akan menyebabkan kehilangan minat pasien untuk berobat dan ini akan menyebabkan pasien mempunyai image negatif terhadap perusahaan tersebut, yang akan mengakibatkan menurunnya jumlah pasien akhirnya akan menyebabkan pengurangan keuntungan.

Parasuraman, et.al (dalam Sunyoto,2014:242) dalam berbagai penelitian mengidentifikasi bahwa ada 5 (lima) dimensi yang digunakan oleh para pelanggan dalam mengevaluasi kualitas layanan tersebut dapat dijelaskan sebagai berikut: 1) Bukti Fisik (Tangible), meliputi fasilitas fisik, perlengkapan, pegawai, dan sarana komunikasi : 2) Keandalan (Realibility), yakni kemampuan memberikan pelayanan yang dijanjikan dengan segera, akurat, dan memuaskan : 3) Daya tanggap (Responsiveness), yaitu keinginan para staf dan karyawan untuk membantu para pelanggan dan memberikan pelayanan dengan tanggap : 4) Jaminan (Assurance), mencakup pengetahuan, kemampuan, kesopanan, dan sifat dapat dipercaya yang dimilki para staf bebas dari bahaya, resiko atau keragu-raguan : 5) Empati (Empaty), meliputi kemudahan dalam melakukan hubungan, komunikasi yang baik, perhatian pribadi, dan memahami kebutuhan para pelanggan.

Kepuasan konsumen merupakan orientasi pemasaran yang semakin penting untuk dilaksanakan, hal ini dimaksud untuk memelihara agar konsumen mau menumbuhkan kepercayaan untuk menggunakan layanan jasa tersebut, Kepuasan merupakan salah satu indikator dalam penilaian kualitas pelayanan di rumah sakit. Perkembangan terakhir menunjukkan bahwa masyarakat pengguna pelayanan kesehatan pemerintah maupun swasta semakin menuntut pelayanan yang bermutu. Masyarakat sebagai konsumen selalu mengharapkan adanya pelayanan yang baik dalam usaha memenuhi kebutuhan dan keinginannya sesuai dengan biaya yang dikeluarkan sehingga dalam pemenuhannya tersebut harus diiringi dengan tingkat kepuasan. Kondisi puas bukan saja bersumber dari barang dan jasa yang dikonsumsi, akan tetapi berkaitan dengan kondisi psikis, pikiran, dan mental konsumen. Baik hal ini muncul sesaat akan mengkonsumsi, maupun karena akumulasi pengetahuan dan pengalamannya. Sehingga pelayanan yang berkualitas akan memberikan kepuasan bagi pelanggan, dengan demikian kepuasan konsumen merupakan landasan utama untuk dapat tumbuh dan berkembang pada era persaingan yang semakin keras.

\section{Permasalahan Penelitian}

Berdasarkan latar belakang penelitian yang telah diuraikan diatas, maka permasalahan dalam penelitian ini adalah : 
1. Apakah kualitas layanan yang terdiri dari Bukti Fisik (Tangibles), Keandalan (Realibility), Daya Tanggap (Responsivens), Jaminan (Assurance), dan Empati (Empaty), secara serempak berpengaruh signifikan terhadap kepuasan pasien rawat inap pada Rumah Sakit Umum Kabupaten Banggai Kepulauan?

2. Apakah kualitas layanan yang terdiri dari Bukti Fisik (Tangibles), Keandalan (Realibility), Daya Tanggap (Responsivens), Jaminan (Assurance), dan Empati (Empaty), secara parsial berpengaruh signifikan terhadap kepuasan pasien rawat inap pada Rumah Sakit Umum Kabupaten Banggai Kepulauan?

\section{Tujuan Penelitian}

Tujuan yang ingin dicapai dalam penelitian ini adalah :

1. Untuk mengetahui pengaruh kualitas layanan yang terdiri dari Bukti Fisik (Tangibles), Keandalan (Realibility), Daya Tanggap (Responsivenss, Jaminan (Assurance) dan Empati (Empaty), terhadap kepuasan pasien rawat inap pada Rumah Sakit Umum Kabupaten Banggai Kepulauan.

2. Untuk mengetahui pengaruh Bukti Fisik (Tangibles) terhadap kepuasan pasien rawat inap pada Rumah Sakit Umum Kabupaten Banggai Kepulauan.

3. Untuk mengetahui pengaruh Keandalan (Realibility) terhadap kepuasan pasien rawat inap pada Rumah Sakit Umum Kabupaten Banggai Kepulauan.

4. Untuk mengetahui pengaruh Daya Tanggap (Responsivenss) terhadap kepuasan pasien rawat inap pada Rumah Sakit Umum Kabupaten Banggai Kepulauan.

5. Untuk mengetahui pengaruh Jaminan (Assurance) terhadap kepuasan pasien rawat inap pada Rumah Sakit Umum Kabupaten Banggai Kepulauan.

6. Untuk mengetahui pengaruh Empati (Empaty) terhadap kepuasan pasien rawat inap pada Rumah Sakit Umum Kabupaten Banggai Kepulauan.

\section{KAJIAN LITERATUR DAN PENGEMBANGAN HIPOTESIS Pengertian Jasa}

Stanton (2001:220) mengatakan bahwa : Jasa adalah kegiatan yang dapat diidentifikasikan secara tersendiri yang pada hakekatnya bersifat tidak terbatas (intangible) yang merupakan pemenuhan kebutuhan dan tidak harus terlihat pada penjualan produk atas jasa yang lain. Untuk menghasilkan jasa mungkin perlu atau tidak perlu penggunaan benda nyata (Tangible). Akan sekalipun penggunaan benda itu perlu namun tidak terdapat adanya pemindahan hak milik benda tersebut.

Menurut Kotler dan Keller (2009:36) jasa/layanan (service) adalah semua tindakan atau kinerja yang dapat ditawarkan satu pihak kepada pihak lain yang pada intinya tidak berwujud dan tidak menghasilkan kepemilkan apapun. Produksinya dapat atau tidak dengan produk fisik.

Berdasarkan beberapa pendapat di atas, maka peneliti menyimpulkan bahwa jasa dapat berupa tindakan apa saja yang bersifat tidak berwujud (intangible) dan tidak menghasilkan hak kepemilikan bagi penggunanya, serta dirancang untuk memuaskannya.

\section{Kualitas Jasa}

Kemampuan suatu perusahaan untuk membuat suatu kualitas produk ataupun jasa dapat mempengaruhi kepuasan dan juga berpengaruh pada penjualan ulang, maka dari itu kualitas sangat penting bagi kelangsungan hidup produk maupun jasa.

Tjiptono (2014:266) mengatakan bahwa kualitas jasa berfokus pada upaya pemenuhan kebutuhan dan keinginan pelanggan serta ketepatan penyampaiannya untuk mengimbangi harapan pelanggan.

Menurut Parasuraman,et.al (dalam Tjiptono,2014:268) mengemukakan bahwa terdapat dua faktor utama yang mempengaruhi kualitas jasa: jasa yang diharapkan (expexted service) dan jasa yang persepsikan (perceived service). Kualitas seringkali disamakan dengan mutu, pendapat demikian diperkuat dengan apa yang dilakukan dalam American Society for Quality Control (dalam Sunyoto,2014:240) menyatakan bahwa kualitas atau mutu merupakan: "Keseluruhan ciri serta sifat barang dan jasa yang berpengaruh pada kemampuannya memenuhi kebutuhan yang dinyatakan maupun yang tersirat". 


\section{Kepuasan Konsumen}

Beberapa ahli pemasaran memberikan definisi mengenai kepuasan dan ketidak puasan konsumen diantaranya: menurut Kotler (2009:177) mengemukakan bahwa kepuasan adalah perasaan senang atau kecewa seseorang yang muncul setelah membandingkan kinerja (hasil) produk yang dipikirkan terhadap kinerja (hasil) yang diharapkan. Jika kinerja berada di bawah harapan, pelanggan tidak puas. Jika kinerja memenuhi harapan, pelanggan puas. Jika kinerja melebihi harapan, pelanggan merasa amat puas atau senang.

Sedangkan arti kepuasan menurut kamus bahasa indonesia adalah sebagai rasa puas, rasa senang dan kelegaan dari seseorang dikarenakan mengkonsumsi suatu produk atau jasa untuk mendapatkan pelayanan jasa.

Menurut Oliver (2009:25) mengemukakan bahwa : "Kepuasan adalah tingkat perasaan seseorang setelah membandingkan kinerja/hasil yang dirasakannya dengan harapannya".

Dari uraian di atas dapat disimpulkan kepuasan konsumen dan ketidak puasan konsumen merupakan dampak dari perbedaan antara harapan dan kinerja aktual yang dirasakan sebelumnya dengan kata lain ketika konsumen membeli suatu produk, sesuai dengan atau melebihi harapannya.

\section{Kualitas Layanan}

Kualitas adalah menjaga janji pelayanan agar pihak yang dilayani merasa puas dan diuntungkan. Memahami tentang arti dari suatu kualitas seperti dijelaskan oleh Goetsh dan Davis (dalam Delfiana,2012:25) mendefinisikan bahwa kualitas merupakan suatu kondisi dinamis yang berhubungan dengan produk, jasa, manusia, proses dan lingkungan yang memenuhi atau melebihi harapan.

Kualitas pelayanan pada umumnya dengan suatu derajat keberhasilan, merupakan derajat kesempurnaan hasil yang melampaui tingkat rata-rata. Produktivitas biasanya selalu dikaitkan dengan kualitas dan profitabilitas. Meskipun demikian ada tiga konsep yang perlu dipertimbangkan (Edvarson, dalam Wini,2012:18) menyebutkan bahwa :

1. Produktivitas menekankan pada pemanfaatan sumber daya, yang seringkali diikuti dengan pengurangan biaya dan rasionalisasi modal. Fokus utamanya adalah produksi.

2. Kualitas lebih menekankan aspek kepuasan pelanggan dan pendapatan. Fokus utamanya customer utility.

3. Profitabilitas merupakan hasil dari hubungan antara penghasilan (income), biaya dan modal yang digunakan.

Prinsip-prinsip di atas, menjelaskan bahwa kualitas pelayanan sangat sulit dievaluasi dan didasarkan pada kinerja yang telah dilakukan oleh penyedia jasa dan persepsi pemakai jasa yang membandingkan antara harapan dan kenyataan yang dirasakan oleh konsumen. Kualitas memiliki hubungan yang berat dengan kepuasan pelanggan dan memberikan suatu dorongan kepada pelanggan untuk menjalin ikatan hubungan yang kuat dengan perusahaan.

Selaian itu, perusahaan juga dapat meningkatkan pangsa pasarnya melalui pemenuhan kualitas atas dorongan pelanggan yang dapat memberikan nilai tambah yang merupakan kombinasi dari manfaat dan pengorbanan yang terjadi apabila pelanggan menggunakan suatu barang dan jasa guna memenuhi kebutuhan tertentu. Bila kualitas yang dihasilkan superior dan pangsa pasar yang dimilki besar, maka profitabilitasnya terjamin. Kualitas dan profitabilitas sangat erat kaitannya.

Kedua pendapat diatas, mengemukakan bahwa : kualitas pelayanan merupakan penyampaian secara excellen atau superior pelayanan yang ditujukan untuk memuaskan pelanggan sesuai dengan persepsi dan harapannya. Dalam mendefiniskan pelayanan yang berkualitas, ada beberapa dimensi pokok yang menjadi pertimbangan dalam perencanaan strategi dan analisis.

1. Tangible (Bukti langsung) meliputi fasilitas fisik, perlengkapan, pegawai, dan sarana komunikasi;

2. Empaty (Empati) meliputi kemudahan dalam melakukan hubungan komunikasi yang baik, perhatian pribadi, dan memahami kebuthan pelanggan;

3. Reability (Keandalan) yaitu kemampuan memberikan pelayanan yang dijanjikan dengan segera, akurat, dan memuaskan;

4. Responsiveness (Daya tanggap) yakni keinginan para staf untuk membantu para pelanggan dan memberikan pelayanan yang tanggap; 
5. Assurance (Kepercayaan) mencakup pengetahuan, kemampuan, kesopanan dan sifat dapat dipercaya yang dimilki oleh para staf, bebas dari bahaya, resiko atau keragu-raguan.

Untuk menerapkan lima dimensi kualitas layanan ke dalam organisasi jasa (Rumah Sakit) dibutuhkan suatu sistem yang menggunakan berbagai macam pendekatan riset secara sistematis untuk mengumpulkan dan menyebarluaskan informasi kualitas layanan guna mendukung pengambilan keputusan. Informasi yang dibutuhkan mencakup berbagai aspek, yaitu data saat ini dan masa lalu baik komunikatif maupun kualitatif, serta informasi mengenai berbagai penyakit yang timbul pada masyarakat dan cara penanganannya.

\section{Kerangka Pemikiran}

Kepuasan pasien rawat inap sangat dipengaruhi oleh kualitas pelayanan yang diterima dari pihak Rumah Sakit Umum Kabupaten Banggai Kepulauan yang digambarkan dalam paradigma penelitian sebagai berikut :

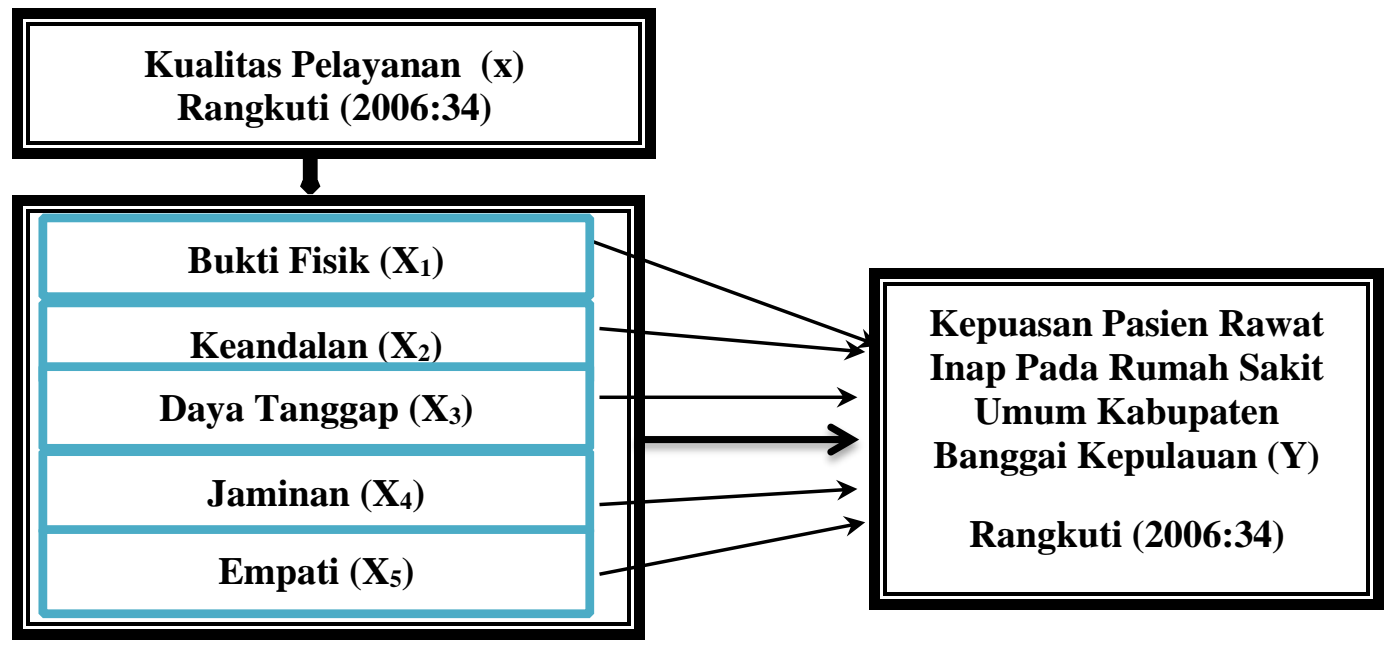

Gambar 1. Kerangka Pemikiran Penelitian

Keterangan :

Pengaruh secara serempak

Pengaruh Secara Parsial

\section{Hipotesis Penelitian}

1. Kualitas layanan yang terdiri atas Bukti Fisik (Tangibles), Keandalan (Realibility), Daya Tanggap (Responsivenss), Jaminan (Assurance) dan Empati (Empaty), secara serempak berpengaruh signifikan terhadap kepuasan pasien rawat inap pada Rumah Sakit Umum Kabupaten Banggai Kepulauan.

2. Kualitas layanan yang terdiri atas Bukti Fisik (Tangibles), Keandalan (Realibility), Daya Tanggap (Responsivenss), Jaminan (Assurance) dan Empati (Empaty), secara parsial berpengaruh signifikan terhadap kepuasan pasien rawat inap pada Rumah Sakit Umum Kabupaten Banggai Kepulauan.

\section{METODE PENELITIAN}

Untuk mengetahui pengaruh kualitas layanan terhadap kepuasan pasien rawat inap pada Rumah Sakit Umum Daerah Kabupaten Banggai Kepulauan digunakan metode penelitian deskriptif, sehingga penelitian dapat menemukan pengaruh kualitas layanan terhadap kepuasan pasien rawat inap di Kabupaten Banggai Kepulauan. Karena pengumpulan dan pengolahan data dalam penelitian adalah berupa angka maka digunakan pendekatan kuantitatif. 


\section{Populasi dan Sampel}

Berdasarkan data pasien pada tahun 2015, jumlah pasien rawat inap sebanyak 1.090 orang. Namun demikian, Data tersebut tidak dapat dijadikan popoulasi dikarenakan :

1) Terdapat pasien yang berobat lebih dari 1 kali

2) Terdapat pasien yang meninggal

3) Terdapat pasien di Luar Wilayah Kota

Dengan demikian, bahwa populasi dalam penelitian ini tidak diketahui jumlahnya (non probability sampling).

Sampel adalah bagian dari jumlah dan karakteristik yang dimilki oleh populasi tersebut (Sugiyono,2013:81). Karena populasinya tidak diketahui, maka teknik pengambilan sampel dalam penelitian ini menggunakan tehnik purposive sampling yaitu responden (subjek) yang dipilih secara sengaja dengan karakteristik tertentu yang diyakini representative terhadap populasi penelitian. Adapun sampel dalam penelitian ini menggunakan kriteria sebagai berikut :

a. Telah berumur 17 tahun ke atas, hal ini disebabkan karena sudah masuk kategori dewasa dan mempunyai kecakapan dalam menjawab pertanyaan peneliti serta bisa bertanggung jawab atas kebenarannya.

b. Responden yang sedang dirawat inap, dalam hal ini pasien yang masih bisa diajak komunikasi dan tidak terlalu parah penyakitnya.

c. Yang pernah menginap minimal 2 hari, dalam hal ini respondennya biasanya ditemui bukan di Rumah Sakit Umum Banggai Kepulauan.

d. Bersedia mengisi kuesioner dan tidak ada paksaan.

Untuk menentukan besar sampel, peneliti merujuk pada teori Roscoe (dalam Sugiyono,2013:130) yang menyatakan bahwa dalam penelitian akan melakukan analisis dengan multivariate (korelasi atau regresi ganda) maka jumlah anggota sampel adalah minimal $10 \mathrm{x}$ dari jumlah variabel yang diteliti (variabel independen + variabel dependen).

Karena jumlah variabel dalam penelitian ini adalah lima (5) yang terdiri dari variabel independen (bukti fisik, keandalan, daya tanggap, jaminan, dan empati) dan satu (1) variabel dependen (kepuasan pasien rawat inap pada Rumah Sakit Umum Banggai Kepulauan), maka berdasarkan pada teori tersebut besar sampel ditentukan sebagai berikut :

$$
12(5+1)=12(6)=72
$$

Jadi jumlah sampel dari penelitian ini sebanyak 72 responden.

Penentuan penggunaan angka 12 adalah untuk menghindari unsur angka minimal yang ditetapkan berdasarkan teori. Dari 72 responden, peneliti dalam mengambil sampel dapat dijelaskan pada tabel sebagai berikut:

Tabel 2 Sampel Penelitian

\begin{tabular}{clc}
\hline No & \multicolumn{1}{c}{ Nama Ruangan Rawat Inap } & Jumlah Pasien \\
\hline 1 & Ruang Rawat Dewasa & 59 orang \\
2 & Ruang Rawat Anak-anak & ------- \\
3 & Ruang Bersalin/Kebidanan & 10 orang \\
4 & Ruang Pelayanan Rawat Darurar & 3 orang \\
& Total & 72 orang \\
\hline
\end{tabular}

Sumber: Data primer diolah, Agustus 2016

\section{Teknik Pengembangan/Pengumpulan Data \\ Metode Pengumpulan Data}

Pengumpulan data dalam penelitian ini dilakukan melalui beberapa teknik yaitu :

1. Observasi (pengamatan), yaitu pengumpulan data dengan melakukan pengamatan langsung terhadap pasien yang sedang dirawat, dengan maksud mengetahui keadaan yang sesungguhnya dalam hal pelayanan yang diberikan kepada pasien di Rumah Sakit Umum Banggai Kepulauan. 
2. Kuesioner, merupakan tehnik pengumpulan data yang dilakukan secara tertulis dengan membagikan selebaran yang berisikan sejumlah pertanyaan berdasarkan indikator-indikator dari variabel penelitian. Penelitian ini menggunakan kuesioner yang dibagikan kepada para responden, yaitu para pasien rawat inap di Rumah Sakit Umum Banggai kepulauan.

3. Wawancara, merupakan tehnik pengumpulan data yang dilakukan untuk memenuhi data sekunder yaitu data yang diperoleh dengan menanyakan langsung kepada beberapa staf mengenai Sejarah Rumah Sakit Umum Kabupaten Banggai Kepulauan, struktur organisasi, dan data pasien selama periode penelitian di Rumah Sakit Umum Banggai Kepulauan.

\section{Definisi Operasional Variabel}

\section{Variabel Bukti Fisik $\left(X_{1}\right)$}

Variabel bukti fisik adalah keberadaan fasilitas-fasilitas fisik, peralatan, sarana komunikasi dan alat-alat pendukung yang berwujud dari Rumah Sakit dalam memberikan pelayanan kepada para pasien

Adapun indikator dari variabel ini adalah :

a) Lokasi parkir yang luas

b) Peralatan pemeriksaan yang lengkap

c) Kenyamanan tempat tidur

d) Penampilan dokter yang selalu rapi

e) Penampilan perawat dan bidan yang selalu rapi

f) Penampilan petugas non medis yang selalu rapi

g) Kebersihan Rumah Sakit

\section{Variabel Keandalan $\left(\mathbf{X}_{2}\right)$}

Variabel Keandalan adalah kemampuan menyediakan pelayanan dengan sikap simpatik, ketepatan waktu pelayanan, profesional dalam melayani pasien, dan sistem pencatatan yang akurat Adapun indikator Keandalan adalah :
a) Prosedur penerimaan pasien tidak berbelit-belit
b) Perawat dan bidan memberikan penjelasan sebelum melakukan pemeriksaan
c) Kemampuan dokter dalam melakukan pemeriksaan
d) Kemampuan perawat dan bidan dalam melakukan pemeriksaan
e) Ketepatan waktu dokter dalam pemeriksaan.
f) Ketepatan waktu perawat dan bidan dalam pemeriksaan

\section{Variabel Daya Tanggap $\left(\mathbf{X}_{3}\right)$}

Variabel daya tanggap adalah perhatian dan kecepatan dalam menghadapi permintaan, pernyataan, keluhan serta kesulitan pasien. Oleh sebab itu penyedia jasa pelayanan kesehatan harus mampu menanggapi setiap keluhan pasien

Adapun indikator dari variabel ini adalah :

a) Kecepatan perawat dan bidan dalam melayani

b) Kecepatan dokter dalam melayani

c) Kecepatan petugas non medis dalam melayani

d) Ketelitian dokter dalam pemeriksaan

e) Ketelitian perawat dan bidan dalam pemeriksaan

f) Kesiapan untuk merespon permintaan pasien

g) Ketepatan diagnosa penyakit

\section{Variabel Jaminan $\left(\mathbf{X}_{4}\right)$}

Variabel Jaminan adalah pasien yang datang akan dilayani secara baik oleh pihak pengelola rumah sakit, akan memberikan rasa aman kepada pasien, sehingga kemantapan pribadi pasien akan bertambah

Adapun indikator dari variabel ini adalah :

a) Dokter ahli sesuai bidangnya

b) Pengobatan yang diberikan dokter mampu mengatasi penyakit

c) Keterampilan petugas administrasi (non medis) dalam menyelenggarakan keuangan 
d) Kesopanan perawat dan bidan

e) Kesopanan dokter

f) Kesopanan petugas non medis

g) Jaminan keamanan pelayanan

\section{Variabel Empati $\left(\mathbf{X}_{5}\right)$}

Variabel empati adalah bagaimana Rumah Sakit meyakinkan pasiennya bahwa mereka itu adalah unik dan istimewa dan dapat digambarkan dengan perhatian secara personal kebutuhan spesifik dan terhadap keluhan pasien dimana pada umumnya pasien ingin diperlakukan dan diperhatikan secara khusus oleh pihak pengelola rumah sakit. Adapun indikator dari variabel ini adalah :

a) Perawat dan bidan memberikan perhatian khusus kepada setiap pasien

b) Dokter memberikan perhatian khusus kepada setiap pasien

c) Perawat dan bidan memahami kebutuhan pasien

d) Dokter selalu bersikap ramah

e) Perawat dan bidan selalu bersikap ramah dalam memberikan pelayanan

f) Petugas non medis selalu bersikap ramah dalam memberikan pelayanan

g) Pelayanan yang diberikan tanpa memandang status sosial

\section{Variabel Kepuasan Konsumen (Y)}

Variabel kepuasan adalah tingkat perasaan seorang pasien setelah membandingkan pelayanan yang diterima dan dirasakan dengan yang diharapkan. Adapun indikator dari variabel ini adalah :

a) Pelayanan yang diberikan sesuai dengan harapan pasien

b) Keyakinan atas kesembuhan pasien dengan pelayanan yang diberikan

c) Biaya yang dikeluarkan pasien sesuai dengan pelayanan yang diberikan

d) Pelayanan kesehatan yang diberikan sesuai dengan prosedur yang telah ditentukan.

e) Pelayanan yang diberikan sesuai dengan keadaan yang dialami pasien.

f) Pelayanan yang diberikan telah memenuhi kebutuhan pasien

\section{Uji Validitas dan Reliabilitas Instrumen penelitian}

Instrumen penelitian yang digunakan dalam penelitian adalah kuesioner atau daftar pertanyaan terstuktur.Sebelum disebarkan kepada responder, instrumen diuji dulu validitas dan reliabilitasnya agar dapat digunakan untuk pengujian lebih lanjut. Adapun hasil uji validitas dan reliablitias kuesioner adalah sebagai berikut dikatakan valid jika nilai corrected item total correlation > 0,6. dikatakan reliabel jika nilai alpha cronbach $>0,6$

\section{Metode Analisis}

Untuk kajian analisis dan pengujian hipotesis, data diolah dan dianalisis denganmenggunakan program SPSS 16.0 for windows, sesuai dengan model yang digunakan yaitu Regresi Linier Berganda:

$$
\mathrm{Y}=\alpha+\mathrm{b}_{1} \mathrm{X}_{1}+\mathrm{b}_{2} \mathrm{X}_{2}+\mathrm{b}_{3} \mathrm{X}_{3}+\mathrm{b}_{4} \mathrm{X}_{4}+\mathrm{b}_{5} \mathrm{X}_{5}
$$

Dimana:

Y = Variabel Kepuasan Pasien Rawat Inap pada Rumah Sakit Umum Kabupaten Banggai Kepulauan
A $\quad=$ Konstanta
$\mathrm{X}_{1} \quad=$ Variabel Bukti Fisik
$\mathrm{X}_{2} \quad=$ Variabel Empati
$\mathrm{X}_{3} \quad=$ Variabel Keandalan
$\mathrm{X}_{4} \quad=$ Variabel Daya Tanggap
$\mathrm{X}_{5} \quad=$ Variabel Jaminan
$\beta_{1,}, \beta_{2}, \beta_{3}, \beta_{4}, \beta_{5}=$ Koefisien regresi 


\section{HASIL DAN PEMBAHASAN}

Setelah dilakukan penghitungan dengan program SPSS version 16 atas data yang telah ditentukan dalam penelitian maka ringkasan hasil olahan data dapat di lihat pada tabel berikut:

Tabel 3 Uji Validitas Instrumen Penelitian

\begin{tabular}{|c|c|c|c|c|c|}
\hline Variabel & $\begin{array}{l}\text { Variabel } \\
\text { Penelitian }\end{array}$ & $\begin{array}{l}\text { Indikator } \\
\text { Penelitian }\end{array}$ & $\begin{array}{c}\text { Corrected } \\
\text { Item Total } \\
\text { Correlatoinal }\end{array}$ & $\begin{array}{c}\mathrm{r} \\
\text { Kritis }\end{array}$ & Ket \\
\hline \multirow{5}{*}{$\begin{array}{c}\text { Kualitas } \\
\text { Layanan } \\
\text { (X) }\end{array}$} & Bukti Fisik (X1) & $\begin{array}{l}\mathrm{X} 1.1 \\
\mathrm{X} 1.2 \\
\mathrm{X} 1.3 \\
\mathrm{X} 1.4 \\
\mathrm{X} 1.5 \\
\mathrm{X} 1.6 \\
\mathrm{X} 1.7\end{array}$ & $\begin{array}{l}.339 \\
.357 \\
.480 \\
.431 \\
.542 \\
.471 \\
.314\end{array}$ & 0,3 & $\begin{array}{l}\text { Valid } \\
\text { Valid } \\
\text { Valid } \\
\text { Valid } \\
\text { Valid } \\
\text { Valid } \\
\text { Valid }\end{array}$ \\
\hline & Keandalan (X2) & $\begin{array}{l}\mathrm{X} 2.1 \\
\mathrm{X} 2.2 \\
\mathrm{X} 2.3 \\
\mathrm{X} 2.4 \\
\mathrm{X} 2.5 \\
\mathrm{X} 2.6\end{array}$ & $\begin{array}{l}.401 \\
.598 \\
.380 \\
.481 \\
.650 \\
.780\end{array}$ & 0,3 & $\begin{array}{l}\text { Valid } \\
\text { Valid } \\
\text { Valid } \\
\text { Valid } \\
\text { Valid } \\
\text { Valid }\end{array}$ \\
\hline & $\begin{array}{c}\text { Daya Tanggap } \\
\text { (X3) }\end{array}$ & $\begin{array}{l}\mathrm{X} 3.1 \\
\mathrm{X} 3.2 \\
\mathrm{X} 3.3 \\
\mathrm{X} 3.4 \\
\mathrm{X} 3.5 \\
\mathrm{X} 3.6 \\
\mathrm{X} 3.7\end{array}$ & $\begin{array}{l}.802 \\
.797 \\
.641 \\
.514 \\
.507 \\
.345 \\
.447\end{array}$ & 0,3 & $\begin{array}{l}\text { Valid } \\
\text { Valid } \\
\text { Valid } \\
\text { Valid } \\
\text { Valid } \\
\text { Valid } \\
\text { Valid }\end{array}$ \\
\hline & Jaminan (X4) & $\begin{array}{l}\mathrm{X} 4.1 \\
\mathrm{X} 4.2 \\
\mathrm{X} 4.3 \\
\mathrm{X} 4.4 \\
\mathrm{X} 4.5 \\
\mathrm{X} 4.6 \\
\mathrm{X} 4.7\end{array}$ & $\begin{array}{l}.645 \\
.617 \\
.616 \\
.774 \\
.701 \\
.822 \\
.692\end{array}$ & 0,3 & $\begin{array}{l}\text { Valid } \\
\text { Valid } \\
\text { Valid } \\
\text { Valid } \\
\text { Valid } \\
\text { Valid } \\
\text { Valid }\end{array}$ \\
\hline & Empati (X5) & $\begin{array}{c}\mathrm{X} 5.1 \\
X 5.2 \\
X 5.3 \\
X 5.4 \\
X 5.5 \\
X 5.6 \\
X 5.7\end{array}$ & $\begin{array}{l}.721 \\
.742 \\
.795 \\
.647 \\
.701 \\
.692 \\
.717\end{array}$ & 0,3 & $\begin{array}{l}\text { Valid } \\
\text { Valid } \\
\text { Valid } \\
\text { Valid } \\
\text { Valid } \\
\text { Valid } \\
\text { Valid }\end{array}$ \\
\hline Kepuasan & Pasien (Y) & $\begin{array}{l}\mathrm{Y} 1 \\
\mathrm{Y} 2 \\
\mathrm{Y} 3 \\
\mathrm{Y} 4 \\
\mathrm{Y} 5 \\
\mathrm{Y} 6\end{array}$ & $\begin{array}{l}.778 \\
.886 \\
.852 \\
.738 \\
.775 \\
.666\end{array}$ & 0,3 & $\begin{array}{l}\text { Valid } \\
\text { Valid } \\
\text { Valid } \\
\text { Valid } \\
\text { Valid } \\
\text { Valid }\end{array}$ \\
\hline
\end{tabular}

Sumber: diolah kembali 
Berdasarkan Tabel 3 di atas, dari 40 indikator yang diukur semua dinyatakan valid, artinya item pernyataan dalam kuesioner tersebut memenuhi syarat digunakan untuk mengukur apa yang hendak diukur dalam penelitian. Hal ini dikarenakan nilai total seluruh indikator (Corrected itemTotal Correlation) lebih besar dari $0.3(\mathrm{r} \geq 0.3)$.

Tabel 4 Uji Reliabilitas Instrumen penelitian

\begin{tabular}{|c|c|c|c|c|}
\hline Variabel & Variabel Penelitian & $\begin{array}{c}\text { Alpha } \\
\text { Cronbach's }\end{array}$ & $\begin{array}{c}\text { Alpha } \\
\text { Toleransi }\end{array}$ & Status Item \\
\hline \multirow{5}{*}{$\begin{array}{l}\text { Kualitas } \\
\text { Layanan } \\
\text { (X) }\end{array}$} & $\begin{array}{l}\text { Bukti Fisik } \\
\text { (X1) }\end{array}$ & .673 & 0.6 & Reliabel \\
\hline & $\begin{array}{l}\text { Keandalan } \\
\quad(\mathrm{X} 2)\end{array}$ & .788 & 0,6 & Reliabel \\
\hline & $\begin{array}{l}\text { Daya Tanggap } \\
\text { (X3) }\end{array}$ & .828 & 0,6 & Reliabel \\
\hline & Jaminan (X4) & .883 & 0,6 & Reliabel \\
\hline & Empati (X5) & .897 & 0,6 & Reliabel \\
\hline $\begin{array}{l}\text { Kepuasan } \\
\text { Pasien } \\
\text { (Y) }\end{array}$ & $\begin{array}{l}\text { Kepuasan } \\
\text { Pelanggan } \\
\text { (Y) }\end{array}$ & .922 & 0,6 & Reliabel \\
\hline
\end{tabular}

Tabel 5 Hasil Perhitungan Regresi Berganda

\begin{tabular}{ccccc}
\hline \multicolumn{5}{c}{ Dependen Variabel Y $=$ Kepuasan Pasien Rawat Inap } \\
\hline Variabel & $\begin{array}{c}\text { Koefisien } \\
\text { Regresi }\end{array}$ & $\begin{array}{c}\text { Standar } \\
\text { Error }\end{array}$ & Sig & Ket \\
(Constant) & -5.751 & 3.046 & .063 & \\
BUKTI FISIK & .122 & .170 & .477 & Tidak Signifikan \\
KEANDALAN & -.261 & .207 & .213 & Tidak Signifikan \\
DAYA TANGGAP & .746 & .168 & .000 & Signifikan \\
JAMINAN & .066 & .166 & .693 & Tidak Signifikan \\
EMPATI & .296 & .144 & .044 & Signifikan \\
\hline R & $=0,834$ & & & \\
R-Square & $=0,696$ & F-hitung $=30,233$ & \\
Adjusted R-Square & $=0,673$ & Sig. F $=0,000$ & \\
\hline Sul &
\end{tabular}

Sumber: diolah kembali

Berdasarkan Tabel di atas, maka disusunlah model regresi berganda sebagai berikut:

$$
Y=-5.751+0,122 X_{1}-0,261 X_{2}+0,746 X_{3}+0,066 X_{4}+0,296 X_{5}
$$

Model persamaan di atas, dapat diartikan sebagai berikut:

a. Nilai konstanta a adalah -5,751 yang menunjukkan bahwa kualitas layanan yang terdiri dari variable bukti fisik $\left(\mathrm{X}_{1}\right)$, keandalan $\left(\mathrm{X}_{2}\right)$, daya tanggap $\left(\mathrm{X}_{3}\right)$, jaminan $\left(\mathrm{X}_{4}\right)$, dan empati $\left(\mathrm{X}_{5}\right)$ arah pengaruhnya negatif terhadap variabel kepuasan pasien (Y). Berarti jika bukti fisik, keandalan, daya tanggap, jaminan, dan empati menigkat sebesar nol (0), maka kepuasan Pasien Rawat Inap 
Pada Rumah Sakit Umum Daerah Kabupaten Banggai Kepulauan akan menurun sebesar -5,751 atau $571,1 \%$. .

b. Nilai koefisien regresi $b_{1}$ adalah 0,122 yang menunjukkan bahwa variabel bukti fisik $\left(\mathrm{X}_{1}\right)$ arah pengaruhnya positif terhadap kepuasan pasien rawat inap pada Rumah Sakit Umum Daerah Kabupaten Banggai Kepulauan. Berarti jika bukti fisik meningkat sebesar 1 satuan, maka kepuasan pasien akan meningkat sebesar 0,122 atau $12,2 \%$.

c. Nilai koefisien regresi $b_{2}$ adalah $-0,261$ yang menunjukkan bahwa variabel keandalan $\left(\mathrm{X}_{2}\right)$ arah pengaruhnya negatif terhadap kepuasan pasien rawat inap pada Rumah Sakit Umum Daerah Kabupaten Banggai Kepulauan. Berarti jika keandalan meningkat sebesar 1 satuan, maka kepuasan pasien akan menurunan sebesar $-0,261$ atau $-26,1 \%$.

d. Nilai koefisien regresi ${ }_{\text {b3 }}$ adalah 0,746 yang menunjukkan bahwa variabel daya tanggap $\left(X_{3}\right)$ arah pengaruhnya positif terhadap kepuasan pasien. Berarti jika daya tanggap meningkat sebesar 1 satuan, maka kepuasan pasien akan meningkat sebesar 0,746 atau 74,6\%.

e. Nilai koefisien regresi $\mathrm{b}_{4}$ adalah 0,066 yang menunjukkan bahwa variabel jaminan $\left(\mathrm{X}_{4}\right)$ arah pengaruhnya positif terhadap kepuasan pasien. Berarti jika jaminan meningkat sebesar 1 satuan, maka kepuasan pasien akan meningkat sebesar 0,066 atau $6,6 \%$.

Nilai koefisien regresi $b_{5}$ adalah 0,296 yang menunjukkan bahwa variabel empati $\left(\mathrm{X}_{5}\right)$ arah pengaruhnya positif terhadap kepuasan pasien. Berarti jika empati meningkat sebesar 1 satuan, maka kepuasan pasien akan meningkat sebesar 0,296 atau 29,6\%.

\section{Pembahasan Atas Hasil Penelitian}

\section{Pengaruh Kualitas Layanan Terhadap Kepuasan Pasien Rawat Inap pada Rumah Sakit Umum Daerah Kabupaten Banggai Kepulauan}

Parasuraman, et.al (dalam Sunyoto,2014:242) mengatakan bahwa ada 5 (lima) dimensi yang digunakan oleh para pelanggan dalam mengevaluasi kualitas layanan dapat dijelaskan sebagai berikut: 1) Bukti Fisik (Tangible), meliputi fasilitas fisik, perlengkapan, pegawai, dan sarana komunikasi : 2) Keandalan (Realibility), yakni kemampuan memberikan pelayanan yang dijanjikan dengan segera, akurat, dan memuaskan : 3) Daya tanggap (Responsiveness), yaitu keinginan para staf dan karyawan untuk membantu para pelanggan dan memberikan pelayanan dengan tanggap : 4) Jaminan (Assurance), mencakup pengetahuan, kemampuan, kesopanan, dan sifat dapat dipercaya yang dimilki para staf bebas dari bahaya, resiko atau keragu-raguan : 5) Empati (Empaty), meliputi kemudahan dalam melakukan hubungan, komunikasi yang baik, perhatian pribadi, dan memahami kebutuhan para pelanggan.

Berdasarkan dari hasil analisis terbukti bahwa secara simultan variabel kualitas layanan yang terdiri dari bukti fisik (X1), keandalan (X2), daya tanggap (X3), jaminan (X4) dan empati (X5) berpengaruh signifikan terhadap variabel kepuasan pasien (Y) pada Rumah Sakit Umum Kabupaten Banggai Kepulauan. Dengan besar pengaruh 69,60 \% sedangkan sisanya 30,40 \% dapat dijelaskan oleh sebab-sebab lain.

ini juga mendukung penelitian terdahulu oleh Any Urwatul Wusko (2014), yang menyatakan bahwa secara simultan variabel kualitas layanan yang terdiri dari bukti fisik (X1), keandalan (X2), daya tanggap (X3), jaminan (X4) dan empati (X5) berpengaruh signifikan terhadap variabel kepuasan pasien $(\mathrm{Y})$.

\section{Pengaruh Variabel Bukti Fisik (X1)}

Parasuraman, et.al (dalam Sunyoto,2014:241) 1. Bukti Fisik (Tangible), meliputi fasilitas fisik, perlengkapan, pegawai, dan sarana komunikasi.

Berdasarkan dari hasil analisis data terbukti secara parsial terdapat pengaruh yang tidak signifikan antara variabel bukti fisik (X1) terhadap variabel kepuasan pasien. Dengan nilai koefisien regresi yaitu sebesar 0,122 atau $12,2 \%$. Hal ini berarti kualitas layanan berupa bukti fisik yang terdiri dari lokasi parkir, peralatan pemeriksaan, kenyamanan tempat tidur, penampilan karyawan yang rapi, dan kebersihan ruangan pada Rumah Sakit Umum Daerah Kabupaten Banggai Kepulauan berpengaruh tidak signifikan terhadap kepuasan pasien, oleh karena itu pihak rumah sakit haruslah senantiasa memperhatikan variabel bukti fisik dengan baik sebagai bentuk mewujudkan kepuasan pasien yang nantinya akan menjadi sumber penyempurnaan kualitas pelayanan RSUD Kabupaten Banggai Kepulauan. 
Hasil dari penelitian ini juga mendukung penelitian terdahulu oleh Any Urwatul Wusko (2014), yang menyatakan bahwa terdapat pengaruh yang tidak signifikan antara variabel bukti fisik (X1) terhadap variabel kepuasan pasien (Y).

\section{Pengaruh Variabel Keandalan (X2)}

Parasuraman, et.al (dalam Sunyoto,2014:241) 2. Keandalan (Realibility), yakni kemampuan memberikan pelayanan yang dijanjikan dengan segera, akurat, dan memuaskan.

Berdasarkan dari hasil analisis data terbukti secara parsial terdapat pengaruh yang tidak signifikan antara variabel keandalan (X2) terhadap variabel kepuasan pasien (Y). Dengan nilai koefisien regresi yaitu sebesar $-0,261$ atau $-26,1 \%$. Hal ini berati kualitas pelayanan berupa keandalan yang terdiri dari Prosedur penerimaan pasien, penjelasan sebelum melakukan pemeriksaan, kemampuan karyawan dalam memeriksa dan ketepatan waktu karyawan dalam melakukan pemeriksaan pada RSUD Kabupaten Banggai Kepulauan berpengaruh tidak signifikan terhadap kepuasan pasien, oleh karena itu pihak rumah sakit harus lebih meningkatkan dan membuktikan kemampuannya dalam memberikan pelayanan yang cepat, tepat dan akurat untuk menciptakan kepuasan pasien. Karena pelayanan yang cepat, tepat dan akurat akan menghindari kejenuhan yang diakibatkan lama menunggu.

Hasil dari penelitian ini juga mendukung penelitian terdahulu oleh Any Urwatul Wusko (2014), yang menyatakan bahwa terdapat pengaruh yang tidak signifikan antara variabel keandalan (X2) terhadap variabel kepuasan pasien (Y).

\section{Pengaruh Variabel Daya Tanggap (X3)}

Parasuraman, et.al (dalam Sunyoto,2014:241) 3. Daya tanggap (Responsiveness), yaitu keinginan para staf dan karyawan untuk membantu para pelanggan dan memberikan pelayanan dengan tanggap.

Berdasarkan dari hasil analisis data terbukti secara parsial terdapat pengaruh yang signifikan antara variabel daya tanggap (X3) terhadap variabel kepuasan pasien. Dengan nilai koefisien regresi yaitu sebesar 0,746 atau 74,6\%. Hal ini berarti kualitas pelayanan berupa daya tanggap yang terdiri dari kecepatan karyawan dalam pemeriksaan, ketelitian karyawan dalam pemeriksaan, kesiapan dalam merespon permintaan pasien dan ketepatan diagnosis penyakit pada RSUD Kabupaten Banggai Kepulauan berpengaruh signifikan terhadap kepuasan pasien. Dari sini sangat jelas bahwa karyawan rumah sakit memegang peranan yang sangat penting dalam memberikan kualitas pelayanan yang mampu memberikan kepuasan pada pasien, karena setiap pasien mempunyai perilaku dan kebiasaan yang berbeda-beda, pengetahuan dan pengalaman yang berbeda-beda, dan kesulitan yang dihadapi juga berbeda-beda. Hal tersebut sangat penting untuk diperhatikan dan terus dipertahankan oleh pihak RSUD Kabupaten Banggai Kepulauan agar pasien merasa puas dengan pelayanan yang ada. Hasil dari penelitian ini juga mendukung penelitian terdahulu oleh Any Urwatul Wusko (2014), yang menyatakan bahwa terdapat pengaruh yang signifikan antara variabel daya tanggap (X3) terhadap variabel kepuasan pasien (Y).

\section{Pengaruh Variabel Jaminan (X4)}

Parasuraman, et.al (dalam Sunyoto,2014:241) 4. Jaminan (Assurance), mencakup pengetahuan, kemampuan, kesopanan, dan sifat dapat dipercaya yang dimilki para staf bebas dari bahaya, resiko atau keragu-raguan.

Berdasarkan dari hasil analisis data terbukti secara parsial terdapat pengaruh yang tidak signifikan antara variabel jaminan (X4) terhadap variabel kepuasan pasien. Dengan nilai koefisien regresi yaitu sebesar 0,066 atau $6,6 \%$. Hal ini berarti kualitas pelayanan berupa jaminan yang terdiri dari kemampuan karyawan dalam mengobati penyakit, keahlian karyawan sesuai bidangnya, keterampilan karyawan, kesopanan karyawan dan jaminan keamanan pelayanan yang diberikan oleh RSUD Kabupaten Banggai Kepulauan berpengaruh tidak signifikan terhadap kepuasan pasien, Oleh karena itu pihak Rumah sakit haruslah senantiasa memperhatikan dan meningkatkan variabel jaminan secara baik agar pelayanan mampu mewujudkan kepuasan pasien.

Hasil dari penelitian ini juga mendukung penelitian terdahulu oleh Any Urwatul Wusko (2014), yang menyatakan bahwa terdapat pengaruh yang tidak signifikan antara variabel jaminan (X4) terhadap variabel kepuasan pasien (Y) 


\section{Pengaruh Variabel Empati (X5)}

Parasuraman, et.al (dalam Sunyoto,2014:241) 5. Empati (Empaty), meliputi kemudahan dalam melakukan hubungan, komunikasi yang baik, perhatian pribadi, dan memahami kebutuhan para pelanggan.

Berdasarkan dari hasil analisis data terbukti secara parsial terdapat pengaruh yang signifikan antara variabel empati (X5) terhadap variabel kepuasan pasien (Y). Dengan nilai koefisien regresi yaitu sebesar 0,296 atau 29,6\%. Hal ini berati kualitas pelayanan berupa empati yang terdiri dari Karyawan dalam memberikan perhatian khusus kepada setiap pasien, karyawan memahami kebutuhan pasien, serta keramahan karyawan dalam memberikan pelayanan pada RSUD Kabupaten Banggai Kepulauan berpengaruh signifikan terhadap kepuasan pasien, oleh karena itu karyawan rumah sakit diharapkan dapat menciptakan komunikasi dan perhatian yang baik bagi pasien. Karena bentuk empati tersebut dapat berpengaruh terhadap pasien.

Hasil dari penelitian ini juga mendukung penelitian terdahulu oleh Any Urwatul Wusko (2014), yang menyatakan bahwa terdapat pengaruh yang signifikan antara variabel empati (X5) terhadap variabel kepuasan pasien (Y)

\section{KESIMPULAN DAN SARAN}

\section{Kesimpulan}

Berdasarkan hasil penelitian dan pembahasan yang telah diuraikan diatas, maka disimpulkan sebagai berikut :

1. Kualitas layanan yang terdiri dari Bukti Fisik (Tangibles), Keandalan (Realibility), Daya Tanggap (Responsivens), Jaminan (Assurance), dan Empati (Empaty), secara serempak berpengaruh signifikan terhadap kepuasan pasien rawat inap pada Rumah Sakit Umum Kabupaten Banggai Kepulauan.

2. Bukti Fisik (Tangibles) berpengaruh tidak signifikan terhadap kepuasan pasien rawat inap pada Rumah Sakit Umum Kabupaten Banggai Kepulauan.

3. Keandalan (Realibility) berpengaruh tidak signifikan terhadap kepuasan pasien rawat inap pada Rumah Sakit Umum Kabupaten Banggai Kepulauan.

4. Daya Tanggap (Responsivenss) berpengaruh signifikan terhadap kepuasan pasien rawat inap pada Rumah Sakit Umum Kabupaten Banggai Kepulauan.

5. Jaminan (Assurance) berpengaruh tidak signifikan terhadap kepuasan pasien rawat inap pada Rumah Sakit Umum Kabupaten Banggai Kepulauan.

6. Empati (Empaty) berpengaruh signifikan terhadap kepuasan pasien rawat inap pada Rumah Sakit Umum Kabupaten Banggai Kepulauan.

\section{Saran}

Berdasarkan simpulan di atas, maka disarankan sebagai berikut.

1. Pihak Rumah Sakit Umum Daerah Kabupaten Banggai Kepulauan, hendaknya lebih memperhatikan pada variabel keandalan yaitu kemampuan menyediakan pelayanan, ketepatan waktu pelayanan, profesional dalam melayani pasien, dan sistem pencatatan yang akurat dalam hal ini mengenai ketepatan waktu Dokter memeriksa, yang kadangkala Dokter melakukan pemeriksaan tidak sesuai jadwal yang telah ditentukan.

2. Untuk peneliti selanjutnya, diharapakan untuk mencari atau menambahkan variabel-variabel yang rendah dengan indikator-indikator yang lainnnya, dan bisa membentuk kepuasan pasien khususnya kualitas layanan pada Rumah Sakit Umum Daerah Kabupaten Banggai Kepulauan , agar hasil penelitiannya memberikan kontribusi yang bermakna pada pihak-pihak yang berkepentingan.

\section{REFERENSI}

Delfiana, (2012). Pengaruh Kualitas Layanan Tehadap Kepuasan Pasien Rawat Inap Pada Rumah Sakit Umum Kabupaten Mamuju Utara, Skripsi, Fakultas Ekonomi Universitas Tadulako, Palu.

Kotler, P. \& Kevin L. K. (2009). Manajemen Pemasaran. (12th ed.1). Jakarta: PT. Mancana Jaya Cemerlang, Jakarta. 
Oliver. (2009). Pelayanan Jasa, Jakarta: Ghalia Indonesia. Rangkuti, Freddy, (2006),

Riset Pemasaran, Jakarta: PT. Gramedia Pustaka Utama.

Sugiyono, (2013). Metode Penelitian Bisnis. Bandung: Alfabeta,

Sugiyono, (2013). Metode Penelitian Administrasi. Bandung: Alfabeta,

Sunyoto, D. (2014). Konsep Dasar Riset Pemasaran Dan Perilaku Konsumen. Yogyakarta: Caps (Center For Academic Publishing Service).

Tjiptono, F. (2014). Pemasaran Jasa, (ed.1). Yogyakarta: C.V Andi Offset.

William J. Stanton. (2001). Fundamental of Marketing, Terjemahan Y. Lamanto. Jakarta: Erlangga.

Wini, Ni Made. (2012). Pengaruh Kualitas Layanan Terhadap Kepuasan Pasien Rawat Jalan Pada Rumah Sakit Umum Kabupaten Mamuju Utara, Skripsi, Fakultas Ekonomi Universitas Tadulako, Palu.

Wusko, Any Urwatul. (2014). Pengaruh Kualitas Pelayanan Terhadap Kepuasan Pengguna Jasa Pada Rumah Sakit Umum Daerah Bangil Kabupaten Pasuruan. Jurnal ketsa Bisnis Vol.1 No. 1. Dosen Program Studi Ilmu Administrasi Niaga. Pasuruan. 